\title{
Effects of prepartum dietary calcium level on calcium and magnesium metabolism in periparturient dairy cows
}

\author{
C. Kronqvist, ${ }^{\star 1}$ U. Emanuelson, $†$ R. Spörndly, ${ }^{*}$ and K. Holtenius ${ }^{\star}$ \\ *Department of Animal Nutrition and Management, Swedish University of Agricultural Sciences, SE-753 23 Uppsala, Sweden \\ †Department of Clinical Sciences, Swedish University of Agricultural Sciences, SE-750 07 Uppsala, Sweden
}

\begin{abstract}
The aim of this study was to investigate the effects of dietary Ca level $(4.9,9.3$, and $13.6 \mathrm{~g} / \mathrm{kg}$ of DM) on $\mathrm{Ca}$ and $\mathrm{Mg}$ homeostasis in dairy cows around parturition. Cows of the Swedish Red breed $(\mathrm{n}=29)$ with no previous veterinary treatment for milk fever were divided into 3 groups, and each group was fed one of the different diets during the last 15 to $32 \mathrm{~d}$ of gestation. Calcium was added as ground limestone, and the $\mathrm{Mg}$ concentration was $1.8 \mathrm{~g} / \mathrm{kg}$ of DM in all diets. After calving the cows were fed similar diets. Plasma was sampled twice per week until calving, and 6, 12, and $24 \mathrm{~h}, 2,4$, and $7 \mathrm{~d}$ after calving. Spot urine samples were collected twice weekly until calving and creatinine was used as a marker of daily urinary excretion. Fecal samples were collected 2 times per day for $5 \mathrm{~d}$ starting 2 wk before expected calving, and acid-insoluble ash was used as an indigestible marker to estimate digestibility. Apparent digestibility of $\mathrm{Mg}$ and daily $\mathrm{Mg}$ excretion in the urine were lower in the dry period for cows fed the highest Ca level. Plasma $\mathrm{Mg}$ concentration was lower on 2,4 , and $7 \mathrm{~d}$ after calving in cows fed the highest level of Ca. Treatment groups did not differ in plasma $\mathrm{Ca}$ concentration, parathyroid hormone concentration, or bone mobilization, evaluated using crosslinked carboxyterminal telopeptides of type I collagen (CTx) as a marker. Plasma Ca concentration decreased and plasma CTx concentration increased $6 \mathrm{~h}$ after calving. The apparent digestibility of Ca during the dry period was not affected by dietary $\mathrm{Ca}$, but the cows fed $4.9 \mathrm{~g} \mathrm{Ca} / \mathrm{kg}$ of $\mathrm{DM}$ excreted $1.2 \mathrm{~g}$ of $\mathrm{Ca} / \mathrm{d}$ in the urine, which was higher compared with $0.4 \mathrm{~g} / \mathrm{d}$ and $0.6 \mathrm{~g} / \mathrm{d}$ for the cows fed $9.3 \mathrm{~g}$ of $\mathrm{Ca} / \mathrm{kg}$ of $\mathrm{DM}$ and $13.6 \mathrm{~g}$ of $\mathrm{Ca} / \mathrm{kg}$ of $\mathrm{DM}$, respectively. The results show that feeding $13.6 \mathrm{~g}$ of dietary $\mathrm{Ca} / \mathrm{kg}$ of DM impaired the $\mathrm{Mg}$ absorption during the dry period, and resulted in decreased plasma $\mathrm{Mg}$ concentration after calving, but prepartum dietary $\mathrm{Ca}$
\end{abstract}

Received December 22, 2009.

Accepted October 30, 2010.

${ }^{1}$ Corresponding author: Cecilia.Kronqvist@huv.slu.se level did not affect plasma $\mathrm{Ca}$, parathyroid hormone, or CTx concentrations.

Key words: magnesium absorption, dry period, parturition

\section{INTRODUCTION}

Parturition and onset of lactation in dairy cows is followed by a large increase in mineral losses due to the high mineral content of milk and colostrum (Shappell et al., 1987) and is associated with a transient decrease in plasma Ca concentration. Milk fever (i.e., periparturient paresis) is a common condition, especially in multiparous cows. The incidence of milk fever differs among herds and can be affected by the mineral composition of the dry cow diet (Lean et al., 2006).

Decreasing the amount of dietary Ca during the last week of gestation has been shown to decrease the incidence of milk fever (Goings et al., 1974; Green et al., 1981). This is assumed to be an effect of adaptation of the Ca homeostatic mechanisms of the cow and better preparation for increased $\mathrm{Ca}$ losses at the onset of lactation. The literature is not consistent regarding in what range of dietary $\mathrm{Ca}$ these positive effects occur. A meta-analysis made by Lean et al. (2006) indicated that a gradual change in dietary Ca from 5 to $10 \mathrm{~g} /$ $\mathrm{kg}$ of DM increased the predicted incidence of milk fever by $327 \%$, and results from Shappell et al. (1987) showed positive effects on plasma Ca concentration at calving by decreasing dietary Ca from 12 to $5 \mathrm{~g} / \mathrm{kg}$ of DM. However, other studies found no beneficial effect on plasma $\mathrm{Ca}$ concentration of a decreased dietary $\mathrm{Ca}$ level within that range (Goff and Horst, 1997; Kamiya et al., 2005). Thilsing-Hansen et al. (2002) suggested that the Ca intake had to be below $20 \mathrm{~g} / \mathrm{d}$ to prevent milk fever, an intake that is difficult to achieve in common dry cow diets.

Parathyroid hormone (PTH) is the main calciumproviding hormone and it increases the mobilization of $\mathrm{Ca}$ from bone tissue, the kidney reabsorption of $\mathrm{Ca}$, and, through vitamin $\mathrm{D}$, the intestinal uptake of $\mathrm{Ca}$ from the diet (Ramberg et al., 1976). Goings et al. (1974) found that cows fed low amounts of dietary Ca 
had a higher PTH concentration in plasma compared with that of control cows. Several studies have shown that PTH increases at calving as a response to the decrease in plasma Ca concentration (Shappell et al., 1987; Kamiya et al., 2005). This results in an increase in Ca mobilization from bone, which is important to re-establish the Ca level in the blood (Yarrington et al., 1976). It has been suggested that at least $48 \mathrm{~h}$ of PTH stimulation is needed to increase mobilization of bone Ca (Goff et al., 1986), and Kamiya et al. (2005) found no significant increase in bone mobilization $3 \mathrm{~d}$ after calving. This is assumed to be an effect of the low activity of the osteoclasts during the dry period, when Ca requirements are well covered by absorption from the diet (Ramberg et al., 1970).

Magnesium has long been known to be important for both the formation of, and the tissue response to, PTH (Anast et al., 1972; Johannesson and Raisz, 1983). Thus, hypomagnesemia decreases the ability to adapt to $\mathrm{Ca}$ deficiency. In adult ruminants, the main site for $\mathrm{Mg}$ absorption is in the rumen, and $\mathrm{Mg}$ is involved in several essential processes in the body, such as energy metabolism, cell proliferation, and muscle contractions. Magnesium is mainly an intracellular ion and only a small fraction is found in the plasma (Malon et al., 2004). It has been shown that high levels of dietary Ca interfere with the ruminal absorption of $\mathrm{Mg}$ in sheep (Care et al., 1984). The effect of Ca levels in dry cow diets on the $\mathrm{Mg}$ homeostasis around parturition is inconsistent among studies. Kamiya et al. (2005) found no effect of dietary $\mathrm{Ca}$ level on plasma $\mathrm{Mg}$ concentration during the dry period or after calving, whereas Verdaris and Evans (1976) observed lower plasma Mg concentration at calving in cows fed $21 \mathrm{~g}$ of $\mathrm{Ca} / \mathrm{kg}$ of DM compared with that in cows fed $2 \mathrm{~g}$ of $\mathrm{Ca} / \mathrm{kg}$ of DM, even though the cows fed the high-Ca diet had a higher $\mathrm{Mg}$ intake. In several studies comparing different $\mathrm{Ca}$ intakes, the $\mathrm{Mg}$ concentration was not similar among diets (Shappell et al., 1987; Goff and Horst, 1997), which makes it difficult to distinguish between effects of dietary $\mathrm{Ca}$ and dietary $\mathrm{Mg}$ on responses in plasma Mg. Green et al. (1981) found no effect of Ca level on periparturient plasma $\mathrm{Mg}$ concentration in cows fed 2 different levels of $\mathrm{Mg}$.

The knowledge is limited and, to some extent, contradictory about the levels of dietary Ca needed to improve Ca homeostasis at calving, as well as how the periparturient plasma $\mathrm{Mg}$ concentration is affected by dry cow diets with different Ca levels. Therefore, the aims of this study were to investigate the effects on periparturient $\mathrm{Ca}$ and $\mathrm{Mg}$ homeostasis, $\mathrm{PTH}$, and bone resorption of feeding varying levels of prepartum dietary $\mathrm{Ca}$ in the range of common dry cow diets, maintaining a constant level of $\mathrm{Mg}$.

\section{MATERIALS AND METHODS}

The study was performed at Kungsängen Research Centre in Uppsala, Sweden, and was approved by the Uppsala Local Ethics Committee.

\section{Animals and Experimental Design}

Thirty dry cows of the Swedish Red breed were used. The breed has a slightly lower incidence of milk fever than the Swedish Holstein breed (i.e., 2.9 and 3.5\%, respectively; Swedish Dairy Association, 2009). The cows had an average weight of $624 \mathrm{~kg}$ (ranging from 488 to $803 \mathrm{~kg}$ ) before the experiment and were divided according to expected calving date into 5 blocks. The cows in each block were divided according to parity number, with cows about to enter their second lactation $(\mathrm{n}=13)$ and cows about to enter their third or more lactation $(\mathrm{n}=17)$ in 2 separate groups. The 2 different parity groups were evenly spread over time, resulting in all blocks but one containing 3 cows from each parity group. The cows in each block and parity group were randomly assigned to 3 different $\mathrm{Ca}$ treatments: $0,4.5$, and $9 \mathrm{~g}$ of additional $\mathrm{Ca} / \mathrm{kg}$ of $\mathrm{DM}$, aiming at diets with $4.5,9$, and $13.5 \mathrm{~g}$ of $\mathrm{Ca} / \mathrm{kg}$ of $\mathrm{DM}$, and all with $1.6 \mathrm{~g}$ of $\mathrm{Mg} / \mathrm{kg}$ of $\mathrm{DM}$, according to NRC recommendations (NRC, 2001). The average production in the herd from September 2007 to August 2008 was $9,498 \mathrm{~kg}$ ECM. None of the cows had previously been treated for milk fever; they were all pregnant and about to enter their second to sixth lactation. The expected calving dates were from October 2007 to May 2008. The cows were housed indoors in individual tie stalls with sawdust bedding on rubber mats during the dry period and had access to water and salt licks during the entire experiment. When the cows showed signs of approaching parturition, they were moved to single-cow calving pens with straw as bedding on a rubber mat. After calving, the cows were kept in the pen with the calf for some hours up to $1 \mathrm{~d}$. They were then moved to individual tie stalls with chopped straw as bedding on rubber mats, where they were kept during the remainder of the experiment. All cows were milked twice daily after calving, at approximately 0630 and $1530 \mathrm{~h}$. One of the multiparous cows calved before receiving the experimental diet and was excluded from the experiment.

\section{Feeding}

During the dry period, the cows were fed 2 times per day (at approximately 0600 and $1700 \mathrm{~h}$ ) with equal amounts of late-cut, high-DM grass silage, and 3 times per day (at approximately 0600, 1200, and $1700 \mathrm{~h}$ ) with 
the experiment, dried at $60^{\circ} \mathrm{C}$ overnight and ground, as for the fecal samples. Samples of the concentrate were collected 3 times during the experiment, dried, and ground, as described for the forage samples. One sample of the limestone was collected.

\section{Analyses}

All feed samples were analyzed for $\mathrm{CP}$ content by the Kjeldahl method (Nordic Committee on Food Analysis, 1976) using a 2020 Digestor and a 2400 Kjeltec analyzer unit (Foss Analytical A/S, Hillerød, Denmark). Dry matter content was determined by overnight drying at $105^{\circ} \mathrm{C}$, and the ash content was determined by heating the samples to $550^{\circ} \mathrm{C}$ for $3 \mathrm{~h}$. The metabolizable energy value of the forage was calculated using the in vitro digestibility (Lindgren, 1979), with the modified regression used as standard in Sweden (Lindgren, 1983). The metabolizable energy values of the concentrates were calculated according to Spörndly (2003). Mineral content of feed, limestone, and feces was analyzed by inductively coupled plasma emission spectrometry (Spectro Analytical Instruments GmbH \& Co., Kleve, Germany) using $\mathrm{HNO}_{3}$ according to the method described by Balsberg-Påhlsson (1990), except for chloride in feeds, which was extracted with $\mathrm{HNO}_{3}$ and determined by titration with $\mathrm{AgNO}_{3}$. Feed, limestone, and feces samples were analyzed for acid-insoluble ash using the method described by van Keulen and Young (1977). The urine was analyzed for creatinine with an autoanalyzer (Technicon, Dublin, Ireland), using the Jaffee reaction, a colorimetric method with picric acid (Technicon, 1974). Plasma and urine were analyzed for Ca using a colorimetric method with O-cresolphthalein (CA 590, Randox, Antrim, UK) and for Mg with a colorimetric method with xylidyl blue (MG 531, Randox), both using a spectrophotometer (Ultrospec K, Boule Nordic, Huddinge, Sweden). Before analysis of $\mathrm{Mg}$, the urine was acidified to $\mathrm{pH} 3$ to 4 with $12 \mathrm{M} \mathrm{HCl}$, with most samples requiring between 1 to $2 \% \mathrm{HCl}$. Plasma was analyzed for crosslinked carboxyterminal telopeptides of type I collagen (CTx) as a marker of bone resorption with a commercial ELISA kit (Serum CrossLaps ELISA, Nordic Bioscience, Herlev, Denmark) using a plate reader (Labsystems Multiscan RC, Helsinki, Finland), and for PTH with a commercially available ELISA kit validated for bovine PTH (Bovine Intact PTH ELISA Kit, Immutopics, San Clemente, CA), using a combined shaker and plate reader (Multiscan FC, Thermo Fisher Scientific, Vantaa, Finland).

\section{Calculations and Statistics}

Acid-insoluble ash was used as an indigestible marker for calculation of the apparent digestibility of $\mathrm{Ca}$ and
Mg. Creatinine was used for calculating the amount of urine excreted each day, assuming a creatinine excretion in urine for all cows of $29 \mathrm{mg} / \mathrm{kg}$ of $\mathrm{BW} \times \mathrm{d}^{-1}$ (Valadares et al., 1999). To avoid problems with few observations on any single day, due to the fact that the cows were sampled only twice per week until calving, time relative to calving was defined as the number of 4-d periods the cow had left to calving at each sampling time before calving, but as 6,12 , and $24 \mathrm{~h}, 2,4$, and $7 \mathrm{~d}$ after calving.

Due to differences between actual calving date and expected calving date, only samples from the last $3 \mathrm{wk}$ of gestation and the first week after calving were used in the multivariable analysis, and samples from the pretreatment period and the first $4 \mathrm{~d}$ of treatment were also not included.

The effect of treatment on plasma concentrations of $\mathrm{Ca}, \mathrm{Mg}, \mathrm{CTx}$, and $\mathrm{PTH}$, and on urinary $\mathrm{pH}$, and daily excretion of $\mathrm{Ca}$ and $\mathrm{Mg}$ was analyzed using separate repeated measures models as implemented in the MIXED procedure of SAS (SAS 9.1, SAS Institute, 2002). A spatial power covariance structure, with cow as the repeated subject and day relative to calving as the coordinate for the distance between observations, was used in the models to account for the repeated observations within cows, except in the model for analysis of differences in PTH levels, in which a first-order autoregressive covariance structure was used because the model did not converge with the spatial power structure. The fixed effects included in the models were treatment group (Tr, 3 levels), parity group (2 levels), block ( 5 levels), time relative to calving (TC, 12 levels), and the interaction $\operatorname{Tr} \times \mathrm{TC}$, and cow was included as a random effect. One primiparous cow fed $13.6 \mathrm{~g}$ of $\mathrm{Ca} / \mathrm{kg}$ of $\mathrm{DM}$ during the dry period was removed from the statistical analysis of the CTx data due to abnormal values with no physiological explanation and high influence on the estimates. The effect of treatment on digestibility was analyzed using a similar model, but the effects of TC, the interaction, and the repeated observations structure were excluded because only one observation per cow was collected. The fixed effects were considered significant at $P<0.05$. Results from the statistical analyses are presented as least squares means. Pairwise comparisons of the least squares means for $\mathrm{Tr}$ at certain time points were only made when there was an overall significant effect. Differences among the groups before receiving the treatments were evaluated with $t$-tests.

\section{RESULTS}

The resulting $\mathrm{Ca}$ and $\mathrm{Mg}$ concentrations of the experimental diets were higher than planned; $4.9 \mathrm{~g}$ of $\mathrm{Ca} /$ $\mathrm{kg}$ of DM ( $\mathrm{n}=10 \mathrm{cows}), 9.3 \mathrm{~g}$ of $\mathrm{Ca} / \mathrm{kg}$ of DM $(\mathrm{n}=9$ 
Table 3. Body weight, parity group composition, treatment period, dry period, gestation length, average dry matter intake $7 \mathrm{~d}$ after calving and disease incidence in the 3 treatment groups (SD shown in parentheses)

\begin{tabular}{lccc}
\hline & \multicolumn{3}{c}{ Treatment, g of Ca/kg of DM } \\
\cline { 2 - 4 } Item & 4.9 & 9.3 & 13.6 \\
\hline BW, kg & $616(58)$ & $631(107)$ & $625(44)$ \\
Parity group 1 and $2^{1}$ & $5+5$ & $4+5$ & $4+6$ \\
Gestation length, $\mathrm{d}$ & $280(5)$ & $282(4)$ & $281(5)$ \\
Treatment period, ${ }^{2} \mathrm{~d}$ & - & $23(6)$ & $24(5)$ \\
Treatment period, ${ }^{2}$ range in d & $9(3)$ & $10(4)$ & $9(2)$ \\
Dry period, wk & $16.8(2.2)$ & $17.4(2.5)$ & $15.9(2.5)$ \\
DMI 1 wk after calving, kg & 0 & 0 & 1 \\
Mastitis, ${ }^{3} \mathrm{n}$ & 1 & 0 & 4 \\
Retained placenta, ${ }^{4} \mathrm{n}$ & & & \\
${ }^{1}$ Parity group 1 = cows calving for the second time; parity & group $2=$ cows calving for the third or more \\
time. & & & \\
${ }^{2}$ Cows fed 4.9 g of Ca/kg of DM were fed this diet during the whole experimental period. & \\
${ }^{3}$ Clinical mastitis occurring up to 7 d after calving. &
\end{tabular}

cows), and $13.6 \mathrm{~g}$ of $\mathrm{Ca} / \mathrm{kg}$ of $\mathrm{DM}(\mathrm{n}=10 \mathrm{cows})$. All groups were fed $1.8 \mathrm{~g}$ of $\mathrm{Mg} / \mathrm{kg}$ of DM. The DCAD values of the diets, calculated as $(\mathrm{Na}+\mathrm{K})-(\mathrm{Cl}+\mathrm{S})$, were 206, 202, and $198 \mathrm{mEq} / \mathrm{kg}$ of $\mathrm{DM}$ for cows fed 4.9, 9.3 , and $13.6 \mathrm{~g}$ of $\mathrm{Ca} / \mathrm{kg}$ of $\mathrm{DM}$, respectively. No feed residues were left from any of the cows during the dry period. None of the cows were paretic or showed clinical signs of milk fever during the experiment. After calving, the intakes of silage and concentrates were gradually increased, and 1 wk after calving the cows were, on average, fed $11.6 \mathrm{~kg}$ of DM of silage/d, $5.2 \mathrm{~kg}$ of DM of concentrates $/ \mathrm{d}$, and $0.1 \mathrm{~kg}$ of mineral supplement/d, resulting in concentrations of $5.8 \mathrm{~g}$ of $\mathrm{Ca}, 3.8 \mathrm{~g}$ of $\mathrm{P}$, $2.7 \mathrm{~g}$ of $\mathrm{Mg}$, and $22.1 \mathrm{~g}$ of $\mathrm{K} / \mathrm{kg}$ of $\mathrm{DM}$ in the total diet. The treatment groups did not differ in terms of postpartum DMI and mineral concentrations, $P>0.20$. Body weight, treatment length, gestation length, dry period length, parity group composition, DMI after calving, and disease incidence in the treatment groups are shown in Table 3. None of the measured variables differed during the pretreatment period.

\section{Plasma Changes at Parturition}

Plasma concentrations of $\mathrm{Ca}, \mathrm{Mg}, \mathrm{CTx}$, and $\mathrm{PTH}$ did not change during the dry period (data not shown), and the values during the last week before calving were, thus, representative for the whole period. A drop in $\mathrm{Ca}$ levels in plasma was evident in all cows at $6 \mathrm{~h}$ postpartum (Figure 1). Plasma Ca values were normalized $4 \mathrm{~d}$ after calving. The decrease in plasma Ca concentration was concurrent with an increase in plasma $\mathrm{Mg}$ and $\mathrm{CTx}$ concentrations (Figure 1). Plasma Mg concentration had returned to prepartum levels $24 \mathrm{~h}$ after calving, and decreased further in the cows fed $13.6 \mathrm{~g}$ of $\mathrm{Ca} /$ $\mathrm{kg}$ of DM, resulting in lower plasma $\mathrm{Mg}$ concentration 2,4 , and $7 \mathrm{~d}$ after calving compared with that of the other treatments. Cows fed $13.6 \mathrm{~g}$ of $\mathrm{Ca} / \mathrm{kg}$ of $\mathrm{DM}$ also had lower plasma $\mathrm{Mg}$ concentration $12 \mathrm{~h}$ after calving compared with that of cows fed $9.3 \mathrm{~g}$ of $\mathrm{Ca} / \mathrm{kg}$ of DM. Plasma CTx remained elevated during the first week after calving $(P<0.01)$. The PTH concentration in plasma was not significantly affected by TC, $P=0.06$ (Figure 1). No effects of treatment group on plasma $\mathrm{Ca}$, plasma CTx, or plasma PTH concentrations were found. Plasma CTx was $0.65 \mathrm{ng} / \mathrm{mL}$ higher in cows calving for the second time compared with that of cows calving for the third time or more, $P=0.033$.

\section{Urinary Excretion}

Time relative to calving did not affect daily urinary excretion of Ca during the prepartum period. The cows fed $4.9 \mathrm{~g}$ of $\mathrm{Ca} / \mathrm{kg}$ of DM excreted more Ca in the urine, $1.2 \pm 0.1 \mathrm{~g} / \mathrm{d}(\mathrm{LSM} \pm \mathrm{SEM})$ compared with $0.4 \pm 0.1$ and $0.6 \pm 0.1 \mathrm{~g} / \mathrm{d}$ for the cows fed 9.3 and $13.6 \mathrm{~g}$ of $\mathrm{Ca} /$ $\mathrm{kg}$ of DM, respectively $(P=0.003)$. Urinary excretion of $\mathrm{Mg}$ was affected by time $(P=0.001)$ and treatment $(P=0.001$, Figure 2). The cows fed $13.6 \mathrm{~g}$ of $\mathrm{Ca} / \mathrm{kg}$ of DM excreted lower amounts of $\mathrm{Mg}$ than did the cows fed 4.9 or $9.3 \mathrm{~g}$ of $\mathrm{Ca}$, and the excretion decreased during the last 3 wk of gestation. No differences existed in urinary $\mathrm{pH}$ over time $(P=0.406)$ or among treatments $(P=0.152)$; the $\mathrm{pH}$ values were $8.0 \pm 0.05,8.1$ \pm 0.05 , and $8.2 \pm 0.05$ for the cows fed 4.9, 9.3, and $13.6 \mathrm{~g}$ of $\mathrm{Ca} / \mathrm{kg}$ of DM, respectively. The concentration of creatinine did not differ among treatment groups $(P$ $=0.621)$, least squares means \pm standard error of the 

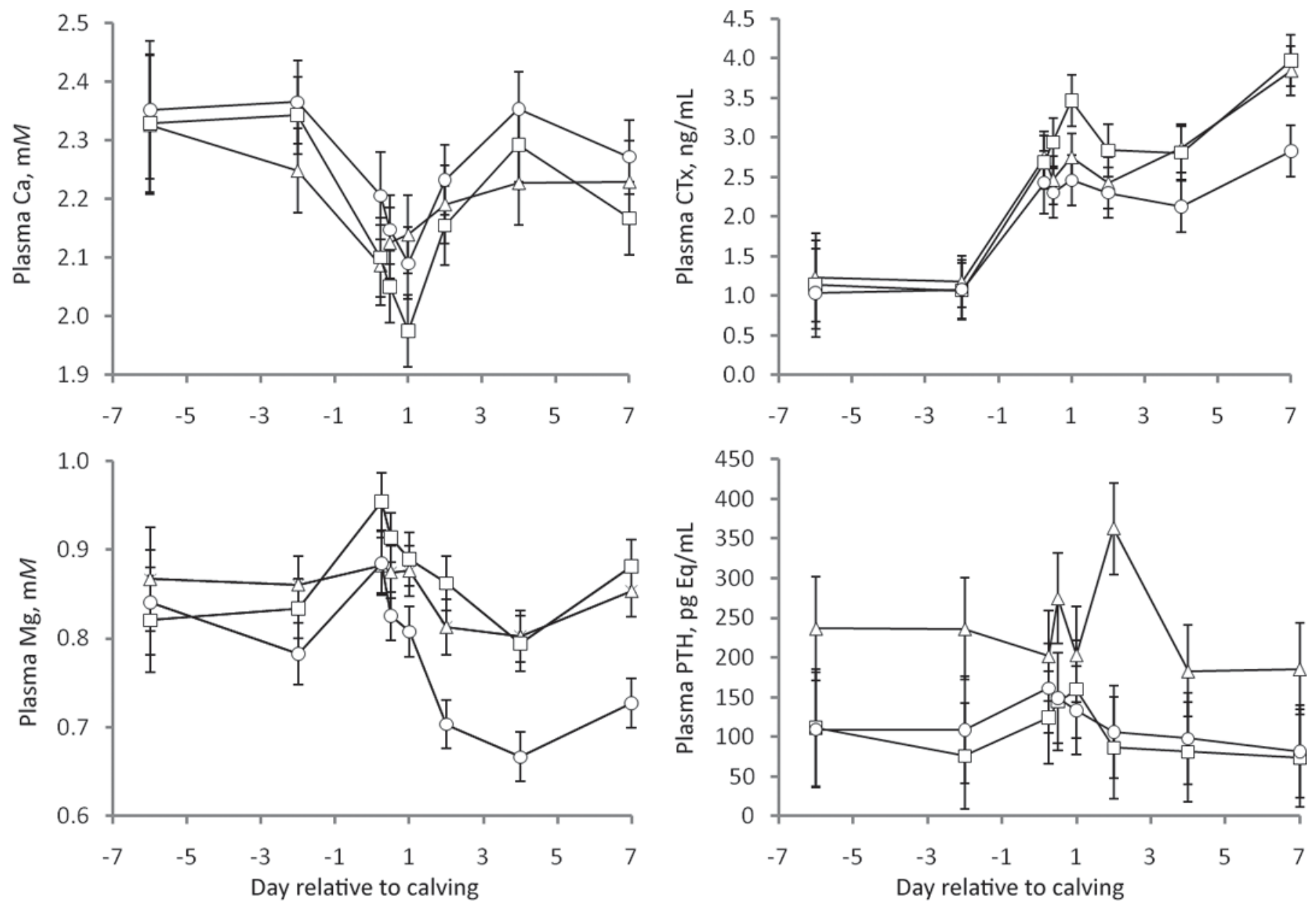

Figure 1. Plasma Ca, Mg, crosslinked carboxyterminal telopeptides of type I collagen (CTx), and parathyroid hormone (PTH; LSM \pm SEM) $1 \mathrm{wk}$ before calving to $1 \mathrm{wk}$ after calving in periparturient cows fed different amounts of Ca during the last 3 wk of the dry period $(\Delta=4.9 \mathrm{~g}$ of $\mathrm{Ca} / \mathrm{kg}$ of DM; $\square=9.3 \mathrm{~g}$ of Ca/kg of DM; $O=13.6 \mathrm{~g}$ of $\mathrm{Ca} / \mathrm{kg}$ of $\mathrm{DM})$. The standard error of the means in the figure is between 0.06 and $0.07 \mathrm{mM}$ for $\mathrm{Ca}, 0.03 \mathrm{~m} M$ for $\mathrm{Mg}$, between 0.31 and $0.34 \mathrm{ng} / \mathrm{mL}$ for CTx, and between 56 and $64 \mathrm{pg} \mathrm{Eq} / \mathrm{mL}$ for PTH.

means were $1.4 \pm 0.17,1.2 \pm 0.18$, and $1.4 \pm 0.17 \mathrm{~g} / \mathrm{L}$ for the cows fed $4.9,9.3$, and $13.6 \mathrm{~g}$ of $\mathrm{Ca} / \mathrm{kg}$ of $\mathrm{DM}$, respectively.

\section{Digestibility of $\mathrm{Ca}$ and $\mathrm{Mg}$}

The different Ca intakes did not affect the calculated apparent digestibility of $\mathrm{Ca} 2 \mathrm{wk}$ before expected calving $(P=0.153)$; the least squares means values \pm standard error of the means were $0.19 \pm 0.04,0.09 \pm 0.04$, and $0.17 \pm 0.04$ for the cows fed 4.9, 9.3, and $13.6 \mathrm{~g}$ of $\mathrm{Ca} / \mathrm{kg}$ of $\mathrm{DM}$, respectively. The apparent digestibility of $\mathrm{Mg}$ was higher in the cows fed the lowest amount of $\mathrm{Ca}(P=0.006), 0.17 \pm 0.04$, compared with $0.05 \pm$ 0.04 and $-0.04 \pm 0.04$ (LSM \pm SEM) for the medium and highest level of dietary $\mathrm{Ca}$, respectively.

\section{DISCUSSION}

The cows fed $13.6 \mathrm{~g}$ of $\mathrm{Ca} / \mathrm{kg}$ of DM during the dry period excreted less $\mathrm{Mg}$ in the urine than did the cows on the other treatments. This indicates that the uptake of $\mathrm{Mg}$ was lowered due to the high level of dietary Ca. This is supported by the lower digestibility of $\mathrm{Mg}$ during the fecal sampling period 2 wk before expected calving. The present result is in line with results of Care et al. (1984) showing that increased Ca concentrations decrease $\mathrm{Mg}$ uptake. Even if the main site of $\mathrm{Ca}$ absorption is in the small intestine, high levels of dietary $\mathrm{Ca}$ are associated with significant net absorption in the forestomachs (Khorasani et al., 1997). It is, thus, reasonable to assume that in the present study, ruminal $\mathrm{Ca}$ absorption interfered with $\mathrm{Mg}$ absorption. This 


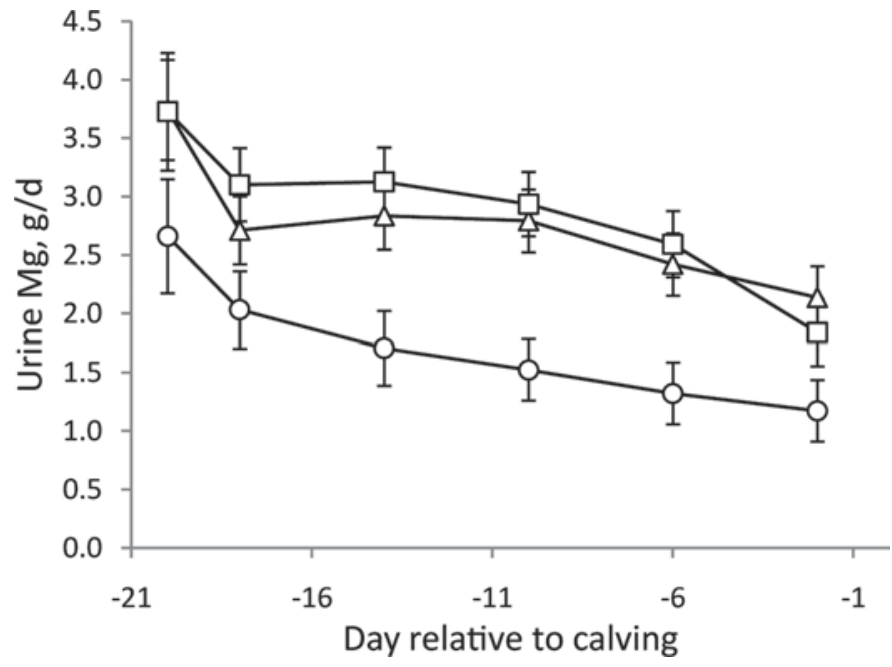

Figure 2. Calculated daily urinary excretion of $\mathrm{Mg}$ from periparturient cows fed different amounts of Ca during the last 3 wk of the dry period $(\Delta=4.9 \mathrm{~g}$ of $\mathrm{Ca} / \mathrm{kg}$ of $\mathrm{DM} ; \square=9.3 \mathrm{~g}$ of $\mathrm{Ca} / \mathrm{kg}$ of $\mathrm{DM} ; \bigcirc=$ $13.6 \mathrm{~g}$ of $\mathrm{Ca} / \mathrm{kg}$ of DM). Data are presented as least squares means \pm standard error of the means. The standard error of the means ranged between 0.26 and $0.50 \mathrm{~g} / \mathrm{d}$.

decreased absorption did not affect plasma $\mathrm{Mg}$ during the dry period. However, $2 \mathrm{~d}$ after calving, plasma $\mathrm{Mg}$ concentration decreased significantly more in the cows that had been fed $13.6 \mathrm{~g}$ of $\mathrm{Ca} / \mathrm{kg}$ of $\mathrm{DM}$, although the dietary mineral concentrations were similar for all cows. A decrease in plasma Mg concentration after calving has been found in previous studies (Verdaris and Evans, 1976). The intracellular pool of $\mathrm{Mg}$ is several times larger than the plasma pool and exchangeable with plasma $\mathrm{Mg}$ (Malon et al., 2004), and, therefore, plasma $\mathrm{Mg}$ concentration is a specific but not very sensitive tool when used to detect $\mathrm{Mg}$ deficiency. In fact, a recent study by Schweigel et al. (2009) indicates that the intracellular pool of $\mathrm{Mg}$ in cattle could be decreased even when plasma $\mathrm{Mg}$ concentration is within the normal range. It is, thus, possible that the reason for the apparent delay in plasma $\mathrm{Mg}$ response to the low $\mathrm{Mg}$ uptake in cows fed $13.6 \mathrm{~g}$ of $\mathrm{Ca} / \mathrm{kg}$ of DM was a gradual depletion of the intracellular $\mathrm{Mg}$ pool, which was only reflected in plasma $\mathrm{Mg}$ after calving, when the losses of $\mathrm{Mg}$ to the milk increased rapidly. The concentration of $\mathrm{Mg}$ in colostrum is about 3 times higher than that in regular milk (Shappell et al., 1987). Although parturition is a natural process, it is associated with pain and stress in the animal (Goff et al., 2002). Stress has been shown to decrease plasma $\mathrm{Mg}$ concentration (Ali et al., 2006). This is suggested to be due to a shift of $\mathrm{Mg}$ from the extracellular to the intracellular compartment because hormones associated with stress may increase the influx of Mg into the cells (Elliott and Rizack, 1974). The stress associated with calving may, thus, have further decreased plasma $\mathrm{Mg}$ concentration after calving.
A plasma $\mathrm{Mg}$ level below $0.74 \mathrm{~m} M$ may be considered as subclinical hypomagnesemic (Mayland, 1988), and a large fraction of the cows had several samples below that limit.

It has been suggested that a urinary excretion of less than $2.5 \mathrm{~g}$ of $\mathrm{Mg} / \mathrm{d}$ in lactating dairy cows indicates inadequate Mg supply (Mayland, 1988). Urinary excretion of $\mathrm{Mg}$ was below $2.5 \mathrm{~g} / \mathrm{d}$ for one or more days in almost all cows in our experiment. Urinary excretion of $\mathrm{Mg}$ is usually a good marker of the $\mathrm{Mg}$ status in the ruminant because excess $\mathrm{Mg}$ is excreted in urine, and our findings indicate that many of the cows were subclinical hypomagnesemic or close to hypomagnesemic, although they were fed a level of dietary $\mathrm{Mg}$ that exceeded the NRC recommendations (NRC, 2001). It is possible that the cut-off value for urinary $\mathrm{Mg}$ excretion in dry cows differs from the value for lactating cows, but 8 cows excreted less than $1 \mathrm{~g}$ of $\mathrm{Mg} / \mathrm{d}$ on at least one sampling, which is clearly very low. The cows fed $13.6 \mathrm{~g}$ of $\mathrm{Ca} /$ $\mathrm{kg}$ of DM contributed to most of the low urinary $\mathrm{Mg}$ samples, but cows from all treatments were represented. This may indicate that feeding Mg slightly above the recommendations was not enough in our study.

Different dietary Ca levels did not significantly affect plasma Ca, PTH, or CTx concentrations. This indicates either that the differences among the dietary concentrations of $4.9,9.3$, and $13.6 \mathrm{~g}$ of $\mathrm{Ca} / \mathrm{kg}$ of $\mathrm{DM}$ were too small to affect the Ca homeostatic mechanisms, or that the lowest level was too high to alter the Ca homeostasis. Thilsing-Hansen et al. (2002) compared several experiments and suggested that dietary Ca levels had to be below $20 \mathrm{~g} / \mathrm{d}$ to prevent parturient paresis, which can be compared with the daily amount of $40 \mathrm{~g}$ for the cows fed $4.9 \mathrm{~g}$ of $\mathrm{Ca} / \mathrm{kg}$ of DM in the present study. However, the results from the meta-analysis of Lean et al. (2006) indicated a gradually increasing milk fever incidence when dietary Ca increased up to about $13 \mathrm{~g} /$ $\mathrm{kg}$ of DM. Our results show that cows fed the lowest amount of $\mathrm{Ca}$ excreted twice as much $\mathrm{Ca}$ in the urine than did cows on the other 2 treatments, which may be a result of an improved Ca absorption and, thereby, an increased need of $\mathrm{Ca}$ excretion in the urine. However, the digestibility of $\mathrm{Ca}$ was not different among treatments and the total amount of Ca excreted in the urine was small compared with the intake in all cows. Urinary excretion of $\mathrm{Ca}$ has been shown to be unaffected by dietary Ca concentration (Verdaris and Evans, 1976), but Ramberg et al. (1976) found a decreased urinary Ca excretion when the cows were fed large amounts of dietary Ca. The acid-base status of the cows seems to have been similar around calving in all treatments because no differences in urinary $\mathrm{pH}$ were found.

The decrease in plasma Ca concentration did not seem to affect the concentration of PTH in our experiment, 
as no significant effect of time on plasma PTH was evident, although the $P$-value was close to significant $(P=0.06)$, with higher values the first days after calving. Results from other studies have shown an increase in PTH concentration at calving (Shappell et al., 1987; Peterson et al., 2005). Hypomagnesemia has been shown to impair the production of PTH (Anast et al., 1972), and the lack of response in PTH in our experiment may have been due to impaired $\mathrm{Mg}$ status in the cows. However, the level of PTH in our experiment was higher than the levels found in some previous studies (Peterson et al., 2005; Penner et al., 2008), and did not follow the same pattern as did the plasma $\mathrm{Mg}$. The reason for the large variation in PTH concentration is unclear. It has been proposed that a lag of up to some days occurs from parturition until bone resorption is significantly increased (Ramberg et al., 1970; Kamiya et al., 2005). In the present study, plasma CTx was increased already at $6 \mathrm{~h}$ after calving, which indicates that the mobilization of $\mathrm{Ca}$ from bone tissue is activated rapidly. Because Ca mobilization from bone could be mediated through different pathways (Fuller et al., 2007), the difference in results probably reflects the choice of bone resorption marker, and CTx has been found to respond to hypocalcemia within hours (Zikan and Stepan, 2009). The fact that PTH concentration was not found to be significantly increased at calving indicates that the activation of bone mobilization, observed as an increase in $\mathrm{CTx}$, depended on other factors than regulation by PTH. Estradiol has been shown to inhibit the mobilization of bone, resulting in decreased formation of $\mathrm{CTx}$ (Prestwood et al., 2000), and the rapid increase in CTx might, therefore, be a result of the decrease in estradiol occurring at parturition (Goff et al., 2002). Holtenius and Ekelund (2005) suggested that estrogen suppressed bone mobilization during the dry period. This is supported by a study made by Liesegang (2008), in which CTx concentration increased after parturition in sheep even if serum Ca concentration did not change. Cows calving for the second time had higher concentrations of CTx in plasma compared with that of older cows. This is in accordance with results from Ekelund et al. (2006) who found that cows had higher CTx value in the dry period before the studied lactation compared with that in the dry period after.

\section{CONCLUSIONS}

Feeding $13.6 \mathrm{~g}$ of $\mathrm{Ca} / \mathrm{kg}$ of DM instead of 4.9 or 9.3 $\mathrm{g}$ of $\mathrm{Ca} / \mathrm{kg}$ of DM for the last 15 to $32 \mathrm{~d}$ of gestation decreased the apparent digestibility and daily urinary excretion of Mg. Plasma Mg concentration in these cows decreased after calving. The different levels of dietary Ca did not affect plasma Ca, CTx, or PTH concentra- tions during the peripartum period, which indicates that restricting the Ca level to $4.9 \mathrm{~g} / \mathrm{kg}$ of DM was not enough to significantly affect Ca status at parturition.

\section{ACKNOWLEDGMENTS}

The authors thank Håkan Wallin (Department of Animal Nutrition and Management, Swedish University of Agricultural Sciences, Uppsala, Sweden) for performing the analyses. The Swedish Farmers' Foundation for Agricultural Research is acknowledged for financial support.

\section{REFERENCES}

Ali, B. H., A. A. Al-Qarawi, and H. M. Mousa. 2006. Stress associated with road transportation in desert sheep and goats, and the effect of pretreatment with xylazine or sodium betaine. Res. Vet. Sci. $80: 343-348$.

Anast, C. S., J. M. Mohs, S. L. Kaplan, and T. W. Burns. 1972. Evidence for parathyroid failure in magnesium deficiency. Science 177:606-608.

Balsberg-Påhlsson, A.-M., ed. 1990. Förbehandling, uppslutning och extraktberedning av växt- och förnaprov. Pages 18-19 in Handledning i Kemiska Metoder vid Växtekologiska Arbeten. Meddelanden från Växtekologiska Avdelningen, Lunds Universitet, Lund, Sweden.

Care, A. D., R. C. Brown, A. R. Farrar, and D. W. Pickard. 1984 Magnesium absorption from the digestive tract of sheep. Q. J. Exp. Physiol. 69:577-587.

Ekelund, A., R. Spörndly, and K. Holtenius. 2006. Influence of low phosphorus intake during early lactation on apparent digestibility of phosphorus and bone metabolism in dairy cows. Livest. Sci. 99:227-236.

Elliott, D. A., and M. A. Rizack. 1974. Epinephrine and adrenocorticotropic hormone-stimulated magnesium accumulation in adipocytes and their plasma membranes. J. Biol. Chem. 249:3985-3990.

Fuller, K., B. Kirstein, and T. J. Chambers. 2007. Regulation and enzymatic basis of bone resorption by human osteoclasts. Clin. Sci. 112:567-575.

Goff, J. P., and R. L. Horst. 1997. Effects of the addition of potassium or sodium, but not calcium, to prepartum rations on milk fever in dairy cows. J. Dairy Sci. 80:176-186.

Goff, J. P., K. Kimura, and R. L. Horst. 2002. Effect of mastectomy on milk fever, energy, and vitamins A, E, and beta-carotene status at parturition. J. Dairy Sci. 85:1427-1436.

Goff, J. P., E. T. Littledike, and R. L. Horst. 1986. Effects of synthetic bovine parathyroid hormone in dairy cows: Prevention of parturient paresis. J. Dairy Sci. 69:2278-2289.

Goings, R. L., N. L. Jacobson, D. C. Beitz, E. T. Littledike, and K. D. Wiggers. 1974. Prevention of parturient paresis by a prepartum, calcium-deficient diet. J. Dairy Sci. 57:1184-1188.

Green, H. B., R. L. Horst, D. C. Beitz, and E. T. Littledike. 1981 Vitamin D metabolites in plasma of cows fed a prepartum lowcalcium diet for prevention of parturient hypocalcemia. J. Dairy Sci. 64:217-226.

Holtenius, K., and A. Ekelund. 2005. Biochemical markers of bone turnover in the dairy cow during lactation and the dry period. Res. Vet. Sci. 78:17-19.

Johannesson, A. J., and L. G. Raisz. 1983. Effects of low medium magnesium concentration on bone resorption in response to parathyroid hormone and 1,25-dihydroxyvitamin D in organ culture. Endocrinology 113:2294-2298.

Kamiya, Y., M. Kamiya, M. Tanaka, and S. Shioya. 2005. Effects of calcium intake and parity on plasma minerals and bone turnover around parturition. Anim. Sci. J. 76:325-330.

Khorasani, G. R., R. A. Janzen, W. B. McGill, and J. J. Kennelly. 1997. Site and extent of mineral absorption in lactating cows 
fed whole-crop cereal grain silage or alfalfa silage. J. Anim. Sci. 75:239-248.

Lean, I. J., P. J. DeGaris, D. M. McNeil, and C. Block. 2006. Hypocalcemia in dairy cows: Meta-analysis and dietary cation anion theory revisited. J. Dairy Sci. 89:669-684.

Liesegang, A. 2008. Influence of anionic salts on bone metabolism in periparturient dairy goats and sheep. J. Dairy Sci. 91:2449 2460.

Lindgren, E. 1979. Vallfodrets näringsvärde bestämt in vivo och med olika laboratoriemetoder. Report 45. Dept. of Animal Nutr. and Management. Swedish Univ. Agric. Sci., Uppsala, Sweden. In Swedish with English summary.

Lindgren, E. 1983. Nykalibrering av VOS-metoden för bestämning av energivärde hos vallfoder. Dept. of Animal Nutr. and Management, Swedish Univ. Agric. Sci., Uppsala, Sweden.

Malon, A., C. Brockmann, J. Fijalkowska-Morawska, P. Rob, and M. Maj-Zurawska. 2004. Ionized magnesium in erythrocytes-The best magnesium parameter to observe hypo- or hypermagnesemia. Clin. Chim. Acta 349:67-73.

Mayland, H. 1988. Grass tetany. Pages 511-523 in The Ruminant Animal: Digestive Physiology and Nutrition. D. C. Church, ed. Prentice Hall, Upper Saddle River, NJ.

Nordic Committee on Food Analysis. 1976. Nitrogen. Determination in food and feed according to Kjeldahl. No. 6. 3rd ed. Nordic Committee on Food Analysis, Oslo, Norway.

NRC. 2001. Nutrient Requirements for Dairy Cattle 7th rev. ed. Natl. Acad. Press, Washington, DC.

Penner, G. B., G. F. Tremblay, T. Dow, and M. Oba. 2008. Timothy hay with a low dietary cation-anion difference improves calcium homeostasis in periparturient Holstein cows. J. Dairy Sci. 91:1959-1968.

Peterson, A. B., M. W. Orth, J. P. Goff, and D. K. Beede. 2005. Periparturient responses of multiparous Holstein cows fed different dietary phosphorus concentrations prepartum. J. Dairy Sci. 88:3582-3594.

Prestwood, K. M., A. M. Kenny, C. Unson, and M. Kulldorff. 2000. The effect of low dose micronized $17 \beta$-estradiol on bone turnover, sex hormone levels, and side effects in older women: A randomized, double blind, placebo-controlled study. J. Clin. Endocrinol. Metab. 85:4462-4469.

Ramberg, C. F., G. P. Mayer, D. S. Kronfeld, J. M. Phang, and M. Bergman. 1970. Calcium kinetics in cows during late pregnancy, parturition, and early lactation. Am. J. Physiol. 219:1166-1177.
Ramberg, C. F., G. P. Mayer, D. S. Kronfeld, and J. T. Potts. 1976. Dietary calcium, calcium kinetics and plasma parathyroid hormone concentration in cows. J. Nutr. 106:671-679.

SAS Institute. 2002. SAS 9.1. SAS Institute Inc., Cary, NC.

Schweigel, M., J. Voigt, and E. Mohr. 2009. Indication of intracellular magnesium deficiency in lactating dairy cows revealed by magnesium loading and renal fractional excretion. J. Anim. Physiol. Anim. Nutr. (Berl.) 93:105-112.

Shappell, N. W., J. H. Herbein, L. J. Deftos, and R. J. Aiello. 1987. Effects of dietary calcium and age on parathyroid hormone, calcitonin and serum and milk minerals in the periparturient dairy cow. J. Nutr. 117:201-207.

Spörndly, R. 2003. Fodertabeller för idisslare. Report 257. Dept. Animal Nutr. Management. Swedish Univ. Agric. Sci., Uppsala, Sweden.

Swedish Dairy Association. 2009. Lägesrapport Djurhälsa 2009. Stockholm, Sweden.

Technicon. 1974. Technicon Method No. SE4-0011FH4. Technicon Instruments Corporation, Tarrytown, NY.

Thilsing-Hansen, T., R. J. Jørgensen, and S. Østergaard. 2002. Milk fever control principles: A review. Acta Vet. Scand. 43:1-19.

Valadares, R. F. D. G. A. Broderick, S. C. Valadares Filho, and M. K. Clayton. 1999. Effect of replacing alfalfa silage with high moisture corn on ruminal protein synthesis estimated from excretion of total purine derivatives. J. Dairy Sci. 82:2686-2696.

Van Keulen, J., and B. A. Young. 1977. Evaluation of acid-insoluble ash as a natural marker in ruminant digestibility studies. J. Anim. Sci. $44: 282-287$.

Verdaris, J. N., and J. L. Evans. 1976. Diet calcium and pH versus mineral balance in Holstein cows 84 days pre- to 2 days postpartum. J. Dairy Sci. 59:1271-1277.

Yarrington, J. T., C. C. Capen, H. E. Black, R. Re, J. T. Potts, and W. B. Geho. 1976. Experimental parturient hypocalcemia in cows following prepartal chemical inhibition of bone-resorption. Am. J. Pathol. 83:569-588.

Zikan, V., and J. J. Stepan. 2009. Marked reduction of bone turnover by alendronate attenuates the acute response of bone resorption marker to endogenous parathyroid hormone. Bone 44:634-638. 